\title{
Inflammatory cytokines and lipid profile in children and adolescents with nephrotic syndrome receiving L. Plantarum: a randomized, controlled feasibility trial
}

\author{
(iD) Patrícia Marques Fortes ${ }^{1}$ \\ (iD) Ricardo Vieira Teles Filho ${ }^{2}$ \\ (iD) Lucas Henrique Souza de Azevêdo² \\ (D) Victória Coelho Jácome Queiroz² \\ (iD) Paulo Sérgio Sucasas da Costa
}

1. Departamento de Pediatria, Hospital das Clínicas, Faculdade de Medicina, Universidade Federal de Goiás (UFG), Goiânia, Goiás, GO, Brasil.

2. Faculdade de Medicina, Universidade Federal de Goiás (UFG), Goiânia, Goiás, GO, Brasil.

http://dx.doi.org/10.1590/1806-9282.66.11.1487

\section{SUMMARY}

This study aimed to evaluate the efficacy of the action of the Lactobacillus Plantarum probiotic as a immunomodulatory and hypolipidemic agent in dyslipidemic nephrotic children and adolescents.

METHODS: This is a randomized, double-blind, placebo-controlled clinical trial in pediatric, compensated or partially compensated nephrotic syndrome and dyslipidemic subjects undergoing regular outpatient follow-up. Serum lipid and TNF- $\alpha$ (proinflammatory) and IL-10 (anti-inflammatory) cytokine variations were evaluated. Cytokines were analyzed by enzyme-linked immunosorbent assay (ELISA). RESULTS: In the probiotic group there was a tendency to reduce TNF- $\alpha$ levels and increase IL-10 levels when compared to controls. Regarding the lipid profile, there was a decrease in serum triglyceride $(6.0 \mathrm{mg} / \mathrm{dL}$ ) and total cholesterol ( $41.5 \mathrm{mg} / \mathrm{dL}$ ) levels in the probiotic group when compared to baseline levels, while in the control group there was an increase in serum triglyceride ( $49.5 \mathrm{mg} / \mathrm{dL}$ ) and total cholesterol $(8.0 \mathrm{mg} / \mathrm{dL}$ ) levels, respectively.

CONCLUSION: Preliminary results suggest that L. Plantarum showed an immunomodulatory and hypolipidemic effect in nephrotic and dyslipidemic pediatric subjects.

KEYWORDS: Child. Inflammation. Probiotics. Hypercholesterolemia. Nephrotic Syndrome.

\section{INTRODUCTION}

Nephrotic syndrome (NS) is a clinical entity characterized by changes in glomerular permeability that result in massive proteinuria, hyperlipidemia, hypoalbuminemia, and generalized edema' ${ }^{1}$. The incidence of NS in childhood is estimated to be $4.7(1,15$ - 16.9) per 100,000 children worldwide. In children, the most common histopathological alteration of NS is called "minimal change disease" (MCD) and is characterized by a good response to corticosteroids in about $80-90 \%$ of the cases².

Over the past decades, significant advances have been made regarding SN pathophysiology. Biomolecular research has demonstrated important changes in $\mathrm{D}$ proteins and in the stability of the podocyte 
cytoskeleton, in addition to the already known hypothesis of immune system dysfunction, are involved in the onset of proteinuria. The acute phase of MCD is characterized by an imbalance in T-cell subpopulations, with a predominance of suppressor T cells (CD8 +) and $\mathrm{T}$ helper cells (Th-1 and Th-2). These cells produce cytokines such as interleukins (IL-1, IL-2, IL-4, IL-12, IL-13, IL-18), tumor necrosis factor-alpha (TNF- $\alpha$ ), and tumor growth factor-beta (TGF- $\beta)^{3}$, which is a trigger for starting and aggravating inflammation ${ }^{4}$. In addition, the participation of monoclonal B cells, immune complexes deposition on glomerular basement membrane (GBM), antigen response, and the presence of antibody receptors located on the surface of glomerular cells are also some of the mechanisms by which the immune system alters the electronegativity and permeability of the GBM, leading to proteinuria ${ }^{2,5,6}$. Hence, the available treatments for SN act on blocking this activation of the immune system.

Massive and persistent proteinuria, which occurs due to changes in the glomerular filtration barrier, results in hypoalbuminemia. This activates hepatic lipoprotein synthesis, which, in the long term, results in dyslipidemia. Thus, patients with SN have increased serum cholesterol levels, triglycerides, intermediate-molecular-weight lipoproteins (IDL), low-molecular-weight lipoproteins (LDL), and apolipoprotein B containing very-low-molecular-weight lipoproteins (VLDL). The persistence of hyperlipidemia in nephrotic individuals is known to play an important role in maintaining inflammation, increasing cardiovascular risk and liponephrotoxicity, accelerating the progression of renal injury. Therefore, for individuals with NS, the binomial dyslipidemia/proteinuria is particularly severe, because the overlapping of factors capable of activating the immune cascade favors the emergence of mechanisms that trigger vascular and renal injury ${ }^{6}$.

Just like inflammation and hyperlipidemia should be treated, there is a growing amount of evidence pointing to a direct and bi-directional interaction between the microbiota and the pathophysiology of renal lesions. On the one hand, progressive uremia may promote changes in metabolism and microbiota composition; on the other hand, many toxins produced by such bacteria (altered microbiota) increase renal injury ${ }^{7},{ }^{8}$. For this reason, the use of probiotics has been drawing attention as concomitant therapy.

Studies demonstrating the impact of the intestinal microbiota on the health of the host have gained scientific interest regarding the use of probiotics as a therapeutic option in several different health problems ${ }^{9}{ }^{11}$. Regarding the possibility of its use in NS, two of the different mechanisms of action of probiotics stood out: 1) the ability to exert immunomodulatory effects when interacting with epithelial, dendritic, monocyte, and macrophage cells ${ }^{12}$, considerably influencing various aspects of the immune system by improving granulocyte phagocytosis, stimulating cytokine secretion in lymphocytes, and modifying T-cell responses (improving Th1 responses and attenuating Th2 responses) ${ }^{12}{ }^{14}$; and 2) its hypolipidemic ability through enzymatic production (bile salt hydrolase), incorporation of cholesterol into the bacterial cell membrane, inhibition of cholesterol transporter in the enterocytes, and inhibition of hepatic cholesterol synthesis ${ }^{15}$.

Therefore, given the complex pathophysiology related to NS and due to these characteristics presented by probiotics, the objective of this paper is to evaluate the efficacy of the Lactobacillus plantarum probiotic as a immunomodulatory and hypolipidemic agent in dyslipidemic children and adolescents with nephrotic syndrome.

\section{METHODS}

This study consists of a randomized, double-blind, placebo-controlled clinical trial in children and adolescents with nephrotic syndrome (NS), under regular outpatient follow-up for more than 1 year at the referral university hospital in the pediatric nephrology service of the Center-West region of Brasil. The research project was approved by the Research Ethics Committee $\left(n^{\circ} 1.733 .937\right)$ and registered in the Brazilian Registry of Clinical Trials (ReBEC - RBR-36byz5).

\section{Selection and sample calculation}

The population consisted of children and adolescents with SN, according to the International Study of Kidney Disease in Children (ISKDC) $)^{16}$ criteria, who were frequent, compensated or partially compensated, and who had dyslipidemia despite the frequent treatment of nephrotic syndrome, and attended the service from June/2016 to July/2017.

For the sample calculation, we used the statistical significance of $5 \%(p<0.05)$ and the power of the twotailed test at $80 \%$. As a reference for the calculation, the data presented in the study by Fuentes et al. ${ }^{17}$ was used as a model. For the sample calculation, the results of total cholesterol and LDL-c after the use of 
L. plantarum or placebo were described as mean and standard error and converted to standard deviation. Thus, the OpenEpi ${ }^{18}$ version 3.01 program was used to perform the calculation, including a $20 \%$ loss potential $(10+20 \%=12$ patients in total), resulting in a total sample of 12 individuals - 6 in the. L. plantarum group (intervention) and 6 in the control group.

\section{Inclusion and exclusion criteria}

Individuals aged 2 to 17 years old, regardless of gender, with MCD or focal and segmental glomerulosclerosis (FSGS), who presented in the last 3 months: $24 \mathrm{~h}$ proteinuria $\leq 50 \mathrm{mg} / \mathrm{kg} /$ day or $<40 \mathrm{mg} / \mathrm{m}^{2}$ body surface area (BSA)/hour, serum albumin $<3.0 \mathrm{~g} / \mathrm{dl}$, total cholesterol $\geq 170 \mathrm{mg} / \mathrm{dl}$ and triglycerides $\geq 130$ $\mathrm{mg} / \mathrm{dl}$, preserved renal function and on or off corticosteroids (dose $\leq 1 \mathrm{mg} / \mathrm{kg} /$ day) and/or cyclosporine (dose $\leq 5 \mathrm{mg} / \mathrm{kg} /$ day). Individuals who had: infectious processes or clinical and/or laboratory decompensation of NS less than 3 months from the beginning of the study, chronic kidney disease stage III or higher, any chronic systemic disease (hypothyroidism, diabetes mellitus, heart disease, lupus) were not admitted, neither were those who were on statins or other hypolipidemic drugs (phytosterols, prebiotics, symbiotics).

\section{Randomization of the groups}

The selected individuals were numbered from 1 to 12 and divided into three groups containing 4 numbers, respectively. Using the software available on www.randomization, the numbers ordered the patients to be enrolled in the study.

\section{Intervention and control characteristics}

The intervention group used the probiotic Lactobacillus plantarum, strain Lp-G18, (Lemma Supply Solutions), purchased as a lyophilized powder and compounded into gelatin capsules, containing 2.5 x 109 CFU/capsule. For the control, $200 \mathrm{mg}$ starch capsules were compounded as the placebo, produced with the same physical characteristics presented in the probiotic capsules, both stored in identical bottles containing 90 capsules.

\section{Study design}

The study was conducted in parallel, divided into 2 groups: a probiotic group, i.e., patients who received L. plantarum orally in capsules containing 2.5 billion CFU, 2x/day for a period of 12 weeks ${ }^{17}$, and a control group, i.e., individuals who received placebo oral capsules containing $200 \mathrm{mg}$ of starch $2 \mathrm{x} /$ day, for another period of 12 weeks.

Subjects underwent four clinical evaluations throughout the study: TO - selection evaluation, application of informed consent form, laboratory tests and guidelines on the removal of fermented foods from the diet; T2 - randomization and distribution of medication; T3 - laboratory evaluation, checking of medication in use and counting of dispensed medication, distribution of new bottle; T4 or endpoint - laboratory evaluation, dispensed medication count and last collection of laboratory tests.

Evaluations were performed every 45 days and consisted of checking weight, height, blood pressure, waist circumference, and certification of adverse events. They were then referred to the laboratory for evaluation of urine test, 24-hour proteinuria, urea, creatinine, serum albumin, total cholesterol, LDL cholesterol, HDL cholesterol, triglycerides, TNF- $\alpha$, and interleukin 10 (IL-10). The dosages of TNF- $\alpha$ and IL-10 were measured by enzyme-linked immunosorbent assay (ELISA).

\section{Statistical evaluation}

A database was created using Microsoft Excel version 2010 and Statistical Package for Social Sciences (SPSS $\left.{ }^{\circledR}\right) 20.0$ for Windows. Descriptive and bivariate analyses were performed considering the significance level of $5 \%(p<0.05)$. The results were submitted to the following statistical tests, taking into consideration the nature of the studied variables: a) measures of central tendency and variability - mean, standard deviation $( \pm$ SD) and mean confidence interval (95\% CI) being evaluated by descriptive statistics; b) Mann-Whitney $\mathrm{U}$ test - was used to compare numerical variables of apparently non-normal distribution.

\section{RESULTS}

A total of 10 patients were selected, of which 4 met the inclusion criteria. The mean age ranged from $9 \pm$ 2.82 years for the probiotic group and $8.5 \pm 6.36$ years for the control group. Each group consisted of 1 boy and 1 girl. Table 1 summarizes the pre-intervention parameters of the probiotic and control groups for serum levels of total cholesterol, LDL, HDL, VLDL, and triglycerides, showing no significant difference between the groups.

After the intervention, the probiotic group showed an average decrease of $41.5 \mathrm{mg} / \mathrm{dl}$ in serum total 
TABLE 1. PRE-INTERVENTION BASELINE VALUES IN THE PROBIOTIC AND CONTROL GROUPS.

\begin{tabular}{l|l|l|l} 
Features & $\begin{array}{l}\text { Probiotic } \\
(\mathrm{n}=2) \\
\text { mean (DP) }\end{array}$ & $\begin{array}{l}\text { Control } \\
(\mathrm{n}=2) \\
\text { mean (DP) }\end{array}$ & P-value* \\
\hline $\begin{array}{l}\text { Total cholesterol (mg/ } \\
\mathrm{dl}),\end{array}$ & $206,5(2,12)$ & $198,0(1,41)$ & 0,121 \\
\hline Total HDL $(\mathrm{mg} / \mathrm{dl})$ & $63,0(29,69)$ & $51,5(6,36)$ & 0,921 \\
\hline VLDL $(\mathrm{mg} / \mathrm{dl})$ & $15,3(1,32)$ & $27,4(23,75)$ & 1,000 \\
\hline LDL $(\mathrm{mg} / \mathrm{dl})$ & $128,2(28,84)$ & $118,0(27,15)$ & 0,439 \\
\hline Triglycerides $(\mathrm{mg} / \mathrm{dl})$ & $76,5(6,36)$ & $137,0(118,79)$ & 1,000 \\
\hline Significance value* $\leq 0,05$. & & &
\end{tabular}

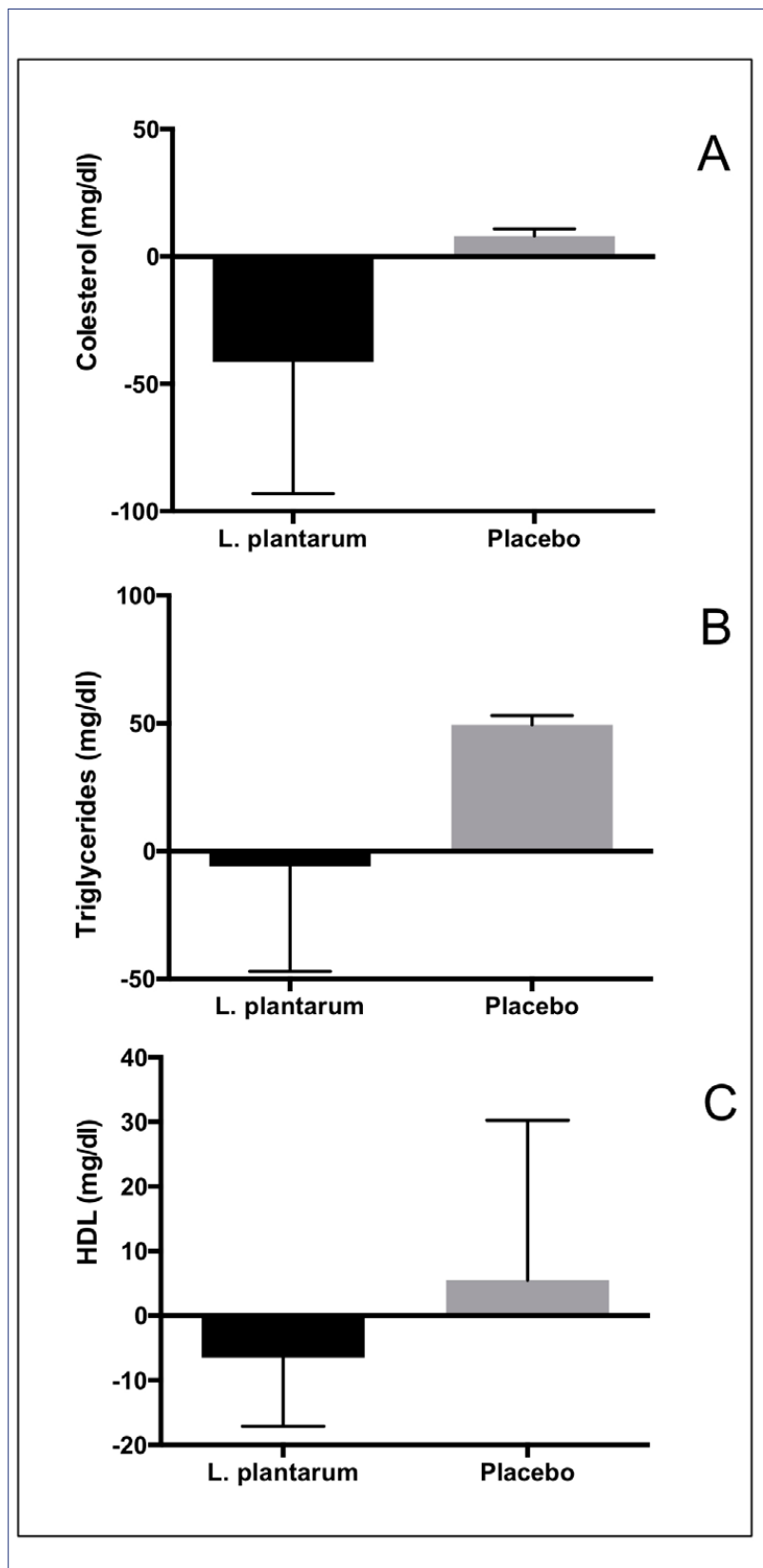

FIGURE 1. VARIATION IN A) TOTAL CHOLESTEROL (P $=0.439), B)$ TRIGLYCERIDES $(P=0.121)$, AND C) HDL $(P=0.121)$ LEVELS IN THE PROBIOTIC AND PLACEBO GROUPS (MANN-WHITNEY'S TEST). cholesterol levels in relation to basal levels. The control group showed a slight increase $(8.0 \mathrm{mg} / \mathrm{dl})$ when compared to normal serum levels. Moreover, in the probiotic group, serum triglyceride levels decreased by $6.0 \mathrm{mg} / \mathrm{dl}$ from baseline, while in the control group there was an increase of $49.5 \mathrm{mg} / \mathrm{dl}$. However, serum HDL levels after the intervention decreased by 6.5 $\mathrm{mg} / \mathrm{dl}$ in the probiotic group when compared to baseline levels and increased by $5.5 \mathrm{mg} / \mathrm{dl}$ in the control group (Figure 1). There were no significant changes in weight and waist circumference measurements during the period. Regarding the serum dosages of inflammatory cytokines, the probiotic group presented a TNF- $\alpha$ value about four times lower $(2,200.47 \mathrm{pg} / \mathrm{ml})$ than that observed in the control group $(8,081.47 \mathrm{pg} /$ $\mathrm{ml})$. IL-10, on the other hand, presented a tendency of increase in the probiotic group of approximately $59 \%(6,718.55 \mathrm{pg} / \mathrm{ml})$ when compared to the control $(4,225.67 \mathrm{pg} / \mathrm{ml})$ (Figure 2).

There were no reports of NS decompensation during the intervention period, nor adverse events or atypical manifestations related to the gastrointestinal tract and systemic. The medicine was checked every 45 days, in order to confirm the proper adherence to treatment.

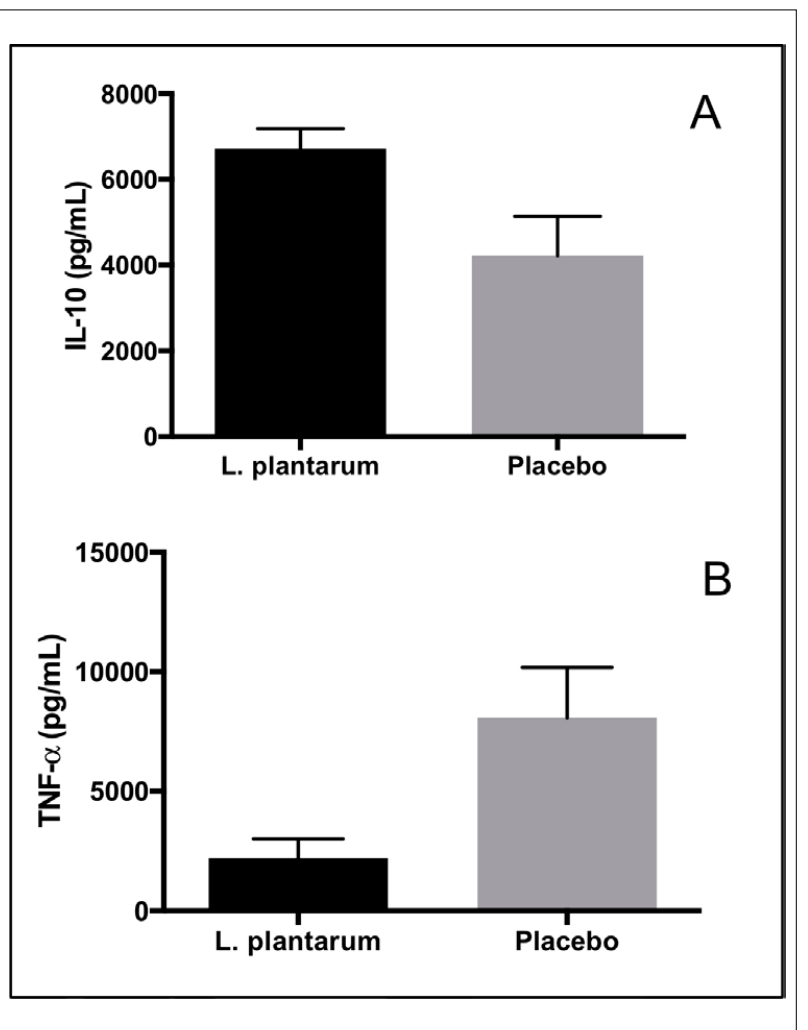

FIGURE 2. VARIATION IN THE LEVELS OF: A) IL-10 $(P=0.131)$ AND B $)$ TNF $(P=0.131)$ IN PROBIOTIC AND PLACEBO GROUPS (MANN-WHITNEY'S TEST). 


\section{DISCUSSION}

The preliminary results presented in this study show a tendency of reduction in serum levels of total cholesterol, triglycerides, and TNF- $\alpha$, and of increase of IL-10, suggesting that L. plantarum probiotic had a satisfactory immunomodulatory and hypolipidemic action in dyslipidemic nephrotic pediatric subjects.

The significant reduction in TNF- $\alpha$ levels observed in this study seemed relevant given the clinical importance of immunomodulation in nephrotic individuals. TNF- $\alpha$ is a proinflammatory cytokine that presents particularly high levels in the acute phase of MCD and FSGS ${ }^{19}$. It stimulates migration, differentiation, proliferation, and cell death. In vascular endothelial cells, these changes induce increased vascular permeability and transendothelial cell migration, favoring atheromatous plaque formation and predisposing to thrombosis ${ }^{20}$. Furthermore, TNF- $\alpha$ also appears to be involved in the podocyte cytoskeleton rearrangement ${ }^{3}$. On the other hand, the use of anti-TNF- $\alpha$ drugs (e,g., etanercept and infliximab) has inexplicably led to NS remission and reduced proteinuria in post-transplanted FSGS children, which serves as clinical evidence of the action ${ }^{20},{ }^{21}$ of TNF- $\alpha$ in the pathophysiology of proteinuria. This study also found a tendency of increased IL-10 in the probiotic group compared to the control. IL-10 exerts a potent anti-inflammatory effect by inhibiting the production of other interleukins, most notably IL-1 and TNF- $\alpha$, and the chemokines responsible for the recruitment of macrophages, monocytes, dendritic cells, and $\mathrm{T}$ cells $\mathrm{s}^{22}$. In regard to the participation of the immune system in the triggering of inflammatory complications in NS, the study was useful in demonstrating that the immunomodulatory action that occurred after the use of L. plantarum could probably prove to be a therapeutic option for controlling this inflammation.

Another beneficial effect observed in the probiotic group after the administration of L. plantarum was the reduction in serum total cholesterol and triglyceride levels compared to pre-intervention levels. To date, no scientific literature was found addressing the use of probiotics in dyslipidemic nephrotic individuals. Nonetheless, the present study showed results similar to those observed in different studies that also used $\mathrm{L}$. plantarum in dyslipidemic individuals and reported a satisfactory lipid profile modification ${ }^{17},{ }^{23},{ }^{24}$.

Limitations regarding the development of the study need to be addressed, and the sample size is the most relevant. Although the study almost reached the number of individuals calculated to compose the sample $(n=12)$, two factors were determinant in the exclusion of these individuals: first the disagreement between the results of examinations from laboratories belonging to the public health network, and the ones provided by the reference laboratory for biochemical analysis. The children invited to participate in the study were submitted to TO to collect exams in the reference laboratory, which in most cases did not confirm the existence of dyslipidemia. Second, relapse of NS or infections within 3 months prior to the recruitment limited the selection of children between 2 and 6 years, since they are more susceptible to common childhood infections. Both situations contained in the inclusion criteria aimed to rule out the possibility of selection bias. Also, no fecal analyzes were performed during and after the intervention to confirm the presence and viability of L. plantarum in the fecal microbiota.

However, even in the absence of definitive conclusions, the results favorably signaled a significant clinical impact in favor of probiotic use in NS, which reinforced the interest in disclosing these results as preliminary to a clinical trial, as already published in other occasions ${ }^{20}$.

\section{CONCLUSION}

Nephrotic syndrome is still a disease of high morbidity despite currently available treatments. Complications secondary to the occurrence of cardiovascular events and liponephrotoxicity in nephrotic individuals are directly related to the silent and persistent evolution of dyslipidemia and inflammation ${ }^{25}$.

Thus, the immunomodulatory and hypolipidemic effects presented in the study after the use of probiotic L. plantarum in dyslipidemic nephrotic children are modest, but present new possibilities to be explored regarding the impact of intestinal microbiota on kidney disease.

\section{Author's Contribution}

PMF and PSC designed the study. PMF, RVTF, LHSA, VCJQ collected the data. PMF, RVTF, LHSA, VCJQ, and PSC did the literature search. PMF, RVTF, LHSA, VCJQ, and PSC wrote the paper. PMF, RVTF, LHSA, VCJQ, and PSC approved the final version of the case report. 
Financial support

None.

\section{Conflicts of interest}

No conflicts of interest to be declared concerning the publication of this article.

\section{RESUMO:}

O objetivo deste estudo foi avaliar a eficácia da ação do probiótico Lactobacillus Plantarum como um agente imunomodulador e hipolipemiante em crianças e adolescentes dislipidêmicos com síndrome nefrótica.

MÉTODOS: Este é um estudo randomizado, duplo-cego, controlado com placebo e realizado em pacientes pediátricos com síndrome nefrótica, compensados ou parcialmente compensados e dislipidêmicos passando por acompanhamento ambulatorial. Variações no lipídio sérico e nas citocinas TNF- $\alpha$ (pró-inflamatória) e IL-10 (anti-inflamatória) foram avaliadas. As citocinas foram analisadas por ensaio imunoenzimático (ELISA).

RESULTADOS: No grupo probiótico, houve uma tendência de redução dos níveis de TNF- $\alpha$ e de aumento dos níveis de IL-10, quando comparado ao controle. Em relação ao perfil lipídico, houve uma diminuição nos níveis séricos de triglicérides $(6,0 \mathrm{mg} / \mathrm{dL})$ e colesterol total $(41,5 \mathrm{mg} / \mathrm{dL})$ no grupo probiótico em comparação aos níveis basais, enquanto no grupo de controle houve um aumento nos níveis séricos de triglicérides $(49,5 \mathrm{mg} / \mathrm{dL}$ ) e colesterol total $(8,0 \mathrm{mg} / \mathrm{dL})$.

CONCLUSÃO: Os resultados preliminares sugerem que o L. Plantarum tem um efeito imunomodulador e hipolipemiante em pacientes pediátricos dislipidêmicos e com síndrome nefrótica.

PALAVRAS-CHAVE: Criança. Inflamação. Probióticos. Hipercolesterolemia. Síndrome Nefrótica.

\section{REFERENCES}

1. Carvalho M, Franco M, Soares V. Glomerulonefrites primárias. In: Riella $M C$, ed. Princípios de nefrologia e distúrbios hidroeletrolíticos. $4^{a}$ ed. Rio de Janeiro: Guanabara Koogan; 2003. p.402-23.

2. Boyer $O$, Tory K, Machuca E, Antignac C. Idiopathic nephrotic syndrome in children: clinical aspects. In: Avner ED, Harmon WE, Niaudet P, Yoshikawa N, Emma F, Goldstein SL, eds. Pediatric nephrology. Heidelberg: Springer Berlin Heidelberg; 2016. p.805-82.

3. van den Berg $\mid G$, Weening $\mid J$. Role of the immune system in the pathogenesis of idiopathic nephrotic syndrome. Clin Sci (Lond). 2004;107(2):125-36.

4. Reidy K, Kaskel FJ. Pathophysiology of focal segmental glomerulosclerosis. Pediatr Nephrol. 2007;22(3):350-4.

5. Nagata M. Immune-mediated glomerular injury in children. In: Avner ED, Harmon WE, Niaudet P, Yoshikawa N, Emma F, Goldstein S, ed. Pediatric nephrology. Heidelberg: Springer Berlin Heidelberg; 2016. p.1-47.

6. Vianna HR, Soares CMBM, Tavares MS, Teixeira MM, Simões e Silva AC. Inflamação na doença renal crônica: papel de citocinas. | Bras Nefrol. 2011;33(3):351-64.

7. Al Khodor S, Shatat IF. Gut microbiome and kidney disease: a bidirectional relationship. Pediatr Nephrol. 2017;32(6):921-31.

8. Evenepoel P, Poesen R, Meijers B. The gut-kidney axis. Pediatr Nephrol. 2017;32(11):2005-14.

9. Tremaroli V, Bäckhed F. Functional interactions between the gut microbiota and host metabolism. Nature. 2012;489(7415):242-9.

10. Kerry RG, Patra JK, Gouda S, Park Y, Shin HS, Das G. Benefaction of probiotics for human health: a review. J Food Drug Anal. 2018;26(3):927-39.

11. Staley $C$, Weingarden $A R$, Khoruts $A$, Sadowsky MJ. Interaction of gut microbiota with bile acid metabolism and its influence on disease states. Appl Microbiol Biotechnol. 2017;101(1):47-64.

12. Gogineni VK, Morrow LE, Malesker MA. Probiotics: mechanisms of action and clinical applications. J Prob Health. 2013;1(1):101. doi:10.4172/jph.1000101.

13. Nagpal R, Kumar A, Kumar M, Behare PV, Jain S, Yadav H. Probiotics, their health benefits and applications for developing healthier foods: a review. FEMS Microbiol Lett. 2012;334(1):1-15.

14. Kechagia M, Basoulis D, Konstantopoulou S, Dimitriadi D, Gyftopoulou K,
Skarmoutsou N, et al. Health benefits of probiotics: a review. ISRN Nutr. 2013;2013:481651.

15. Reis SA, Conceição LL, Rosa DD, Siqueira NP, Peluzio MCG. Mechanisms responsible for the hypocholesterolaemic effect of regular consumption of probiotics. Nutr Res Rev. 2017;30(1):36-49.

16. Churg J, Habib R, White RR. Pathology of the nephrotic syndrome in children: a report for the International Study of Kidney Disease in Children. Lancet. 1970;760(1):1299-302.

17. Fuentes MC, Lajo T, Carrión JM, Cuñé J. Cholesterol-lowering efficacy of Lactobacillus plantarum CECT 7527, 7528 and 7529 in hypercholesterolaemic adults. Br J Nutr. 2013;109(10):1866-72.

18. Dean A, Sullivan K, Soe M. OpenEpi: open source epidemiologic statistics for public health. Version 3.01. [cited 2020 Mar 10]. Available from: www. openepi.com

19. Suranyi MG, Guasch A, Hall BM, Myers BD. Elevated levels of tumor necrosis factor-alpha in the nephrotic syndrome in humans. Am | Kidney Dis. 1993;21(3):251-9.

20. Weissbach A, Garty BZ, Lagovsky I, Krause I, Davidovits M. Serum tumor necrosis factor-alpha levels in children with nephrotic syndrome: a pilot study. Isr Med Assoc J. 2017;19(1):30-3.

21. Leroy $S$, Guigonis V, Bruckner D, Emal-Aglae V, Deschênes G, Bensman A, et al. Successful anti-TNFalpha treatment in a child with posttransplant recurrent focal segmental glomerulosclerosis. Am J Transplant. 2009;9(4):858-61.

22. Moore KW, de Waal Malefyt R, Coffman RL, O'Garra A. Intereleukin-10 and the interleukin-10 receptor. Annu Rev Immunol. 2001;19:683-765.

23. Naruszewicz M, Johansson ML, Zapolska-Downar D, Bukowska H. Effect of Lactobacillus plantarum 299v on cardiovascular disease risk factors in smokers. Am J Clin Nutr. 2002;76(6):1249-55.

24. Ishimwe N, Daliri EB, Lee BH, Fang F, Du G. The perspective on cholesterol-lowering mechanisms of probiotics. Mol Nutr Food Res. 2015;59(1):94-105.

25. Candan C, Canpolat N, Gökalp S, Yıldız N, Turhan P, Taşdemir M, et al. Subclinical cardiovascular disease and its association with risk factors in children with steroid-resistant nephrotic syndrome. Pediatr Nephrol. 2014;29(1):95-102. 